\title{
Structural failure process of schistosity rock under microwave radiation at high temperatures
}

\author{
Leping He, Yucheng Gu, Qijun Hu, Yuan Chen, Junsen Zeng \\ School of Civil Engineering and Architecture, Southwest Petroleum University, Chengdu 610500, China \\ 201231010028@swpu.edu.cn,guyucheng0728@163.com,buqijunswpu@163.com,965742308@qq.com, \\ zengjunsenwork@163.com
}

ABSTRACT. The effects of high temperature induced by microwave radiation on the schistosity structural rock were investigated. A $1.45 \mathrm{~kW}$ commercial microwave system was employed to irradiate specimens to a designed temperature $\left(300-800{ }^{\circ} \mathrm{C}\right)$ for 15 minutes. Cracking and local melting initially appeared in the biotite enrichment area at $500{ }^{\circ} \mathrm{C}$. Macro-cracks in the dark area were parallel to the schistosity trend, owing to the weak connection in a direction perpendicular to the schistosity plane. The composition of the rock did not significantly change before and after microwave radiation. The diffraction peak intensity of the biotite decreased with temperature increase, owing to melting. The average peak stress decreased significantly with increasing temperature. It is concluded that the high temperature induced by microwave radiation promotes hard rock breakage and the schistosity structure of rock significantly affects the cracking pattern.

KEYwORDS. Microwave radiation; Schistose granite; High temperature; Thermal damage.

\section{OPEN ACCESS}

Citation: He, L., Gu, Y., Hu, G., Chen, Y., Zeng, J., Structural failure process of schistosity rock under microwave radiation at high temperatures, Frattura ed Integrità Strutturale, 50 (2019) 649-657.

Received: 17.07.2019

Accepted: 11.09.2019 Published: 01.10.2019

Copyright: (C) 2019 This is an open access article under the terms of the CC-BY 4.0, which permits unrestricted use, distribution, and reproduction in any medium, provided the original author and source are credited.

\section{INTRODUCTION}

I ncreasing the efficiency of hard rock breakage is a common issue in mining, tunnelling, and nuclear waste disposal [13]. Traditional hard rock breakage methods (such as mechanical excavation and blasting), are problematic because they consume much energy, are expensive, and contribute to pollution. Considering the characteristics of rapid volumetric heating, selective heating, and instantaneous control, microwave radiation is considered as a potential method for rock comminution processes.

Since Maurer [4] suggested the usage of microwaves for rock breakage in the 1960s, many studies have demonstrated that microwave radiation could effectively reduce the mechanical performance of rocks [5-7]. Minerals can absorb microwave energy and convert it into heat energy. The dielectric properties of minerals determine the capacity for absorbing and converting microwaves [8,9]. Lu et al. [7] suggested that the microwave susceptibility of rock-forming minerals could be linked to the content of ferrum. Therefore, temperature gradients would be produced in the irradiated rock, reducing the strength of the rock by yielding micro- and macro-cracks [10-12]. The water content, the size and location of grains, can affect the initiation and propagation of cracks $[13,14]$. Also, the microwave radiation conditions, including the microwave 
power level, the distance to rock, and the radiation time, were also shown to affect the intensity and distribution of temperature $[12,15]$. In addition to experiments, many researchers used numerical simulations to understand the failure processes in a rock exposed to microwave radiation. Whittles et al. [16] studied the influence of electric field strength on a two-phase rock under microwave radiation, and found that both the highest temperature and the highest temperature gradient occurred during the microwave-absorbing phase. Subsequently, other researchers [17,18] also showed that cracks originate around mineral crystals. Further, they found that microwave power, radiation time, and the ratio of the absorption phase to the transparent phase also affect the rock destruction results. In addition, the anisotropy, the dimensions and shapes of minerals affect the cracking of rock under microwave radiation [19-22].

Although significant research was done on this topic, there are only a few studies that address the effect of mineral distribution on rock structural failure under microwave radiation, such as schistosity. The schistosity structure of rock has been demonstrated to significantly affect the fracture patterns under mechanical loadings [23,24]. In addition, the failure of rock under microwave radiation (such as cracking and melting) was generally considered to reflect cumulative thermal damage, and failure was considered to occur gradually with increasing temperature [25-27]. Therefore, for a better understanding of the effect of microwave treatment on rocks, a study that addresses the effect of mineral distribution on the failure processes at high temperatures is necessary.

This paper study focuses on investigating the response of schistosity structural rock to increasing temperature induced by microwave radiation. After microwave radiation, the microstructure, mineral composition, crystallisation changes, and mechanical performance were analysed to explain the failure mechanism in the schistosity structural rock under microwave radiation.

\section{MATERIALS AND METHODS}

\section{Materials}

he granite was obtained from the Qingyuan region of Liaoning province of China and it showed a clear schistosity structure. As shown in Fig. 1a, the rock block could be divided into dark and pale layers. The petrographic microscopic image of granite was prepared for observation using a polarising microscope (LABORLUX12 pol, Leitz). The petrographic thin section (Fig. 1b) shows that the Qingyuan granite has a medium-fine grain structure and is mainly composed of $65 \%$ feldspar, $22 \%$ quartz, and $11.5 \%$ biotite. In addition, most minerals exist in different degrees of alteration, such as feldspar as sericite. X-ray fluorescence (XRF, PANalytical B.V. Axios) was used to further determine the chemical compositions of the dark and pale areas, respectively, and the results are listed in Tab. 1. Tab. 1 shows that femic minerals (such as biotite) are mainly distributed in the dark area, while the light area is mainly composed of feldspar and quartz.
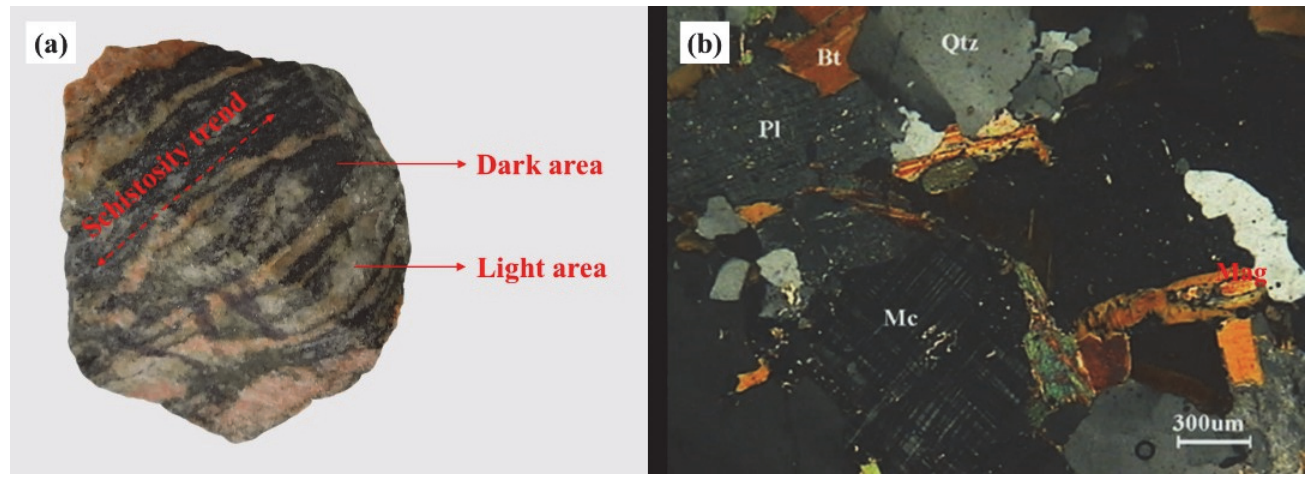

Figure 1: Appearance picture (a) and petrographic microscopy image (b) of virgin granite. (Pl-plagioclase; Mc-microcline; Qtz-quartz; Bt-biotite; Mag- magnetite).

\begin{tabular}{ccccccccc}
\hline & Oxide & $\mathrm{SiO}_{2}$ & $\mathrm{Al}_{2} \mathrm{O}_{3}$ & $\mathrm{Na}_{2} \mathrm{O}$ & $\mathrm{K} 2 \mathrm{O}$ & $\mathrm{Fe}_{2} \mathrm{O}_{3}$ & $\mathrm{CaO}$ & $\mathrm{MgO}$ \\
Content / wt.\% & 65.61 & 16.89 & 2.33 & 3.12 & 5.70 & 3.41 & 1.42 \\
Dark area & 78.61 & 10.79 & 1.68 & 6.00 & 0.22 & 1.74 & 0.07 \\
Pale area & & 6 &
\end{tabular}

Table 1: Chemical composition of rock. 
Experimental procedures

Microwave radiation experiments were performed in a commercial microwave muffle furnace (HAMiLab-M1500), operating at a frequency of $2.45 \mathrm{GHz}$, as shown in Fig. 2. According to the set temperature curve, the microwave system can automatically adjust and continuously output power in the $0.2-1.4 \mathrm{~kW}$ range. The cavity was equipped with an infrared thermometer to measure the surface temperatures of the analysed specimen. Therefore, the temperatures described below refer to the surface temperatures of the analysed samples. It should be noted that according to the principle of microwave heating, the temperature inside the samples is higher than the surface.

Considering the dimensions of the microwave cavity, the granite block was processed into cube-shaped samples (side length, $2.5 \mathrm{~cm}$ ) and dried at $105^{\circ} \mathrm{C}$, until obtaining constant weight blocks. Rocks with no visible macro-cracks in six surfaces were selected as test specimens. Each set contained two specimens and only one was heated during each test. To avoid the high loss rate of heat, the specimens were placed into the cavity of alumina for thermal insulation. The temperature curve was set with the rate of increase of $10-20{ }^{\circ} \mathrm{C}$ per minute and was maintained for 15 minutes after reaching the 6 designated temperatures $\left(300-800{ }^{\circ} \mathrm{C}\right.$ with steps of $\left.100^{\circ} \mathrm{C}\right)$, following which the specimens were cooled to room temperature naturally in the microwave device.

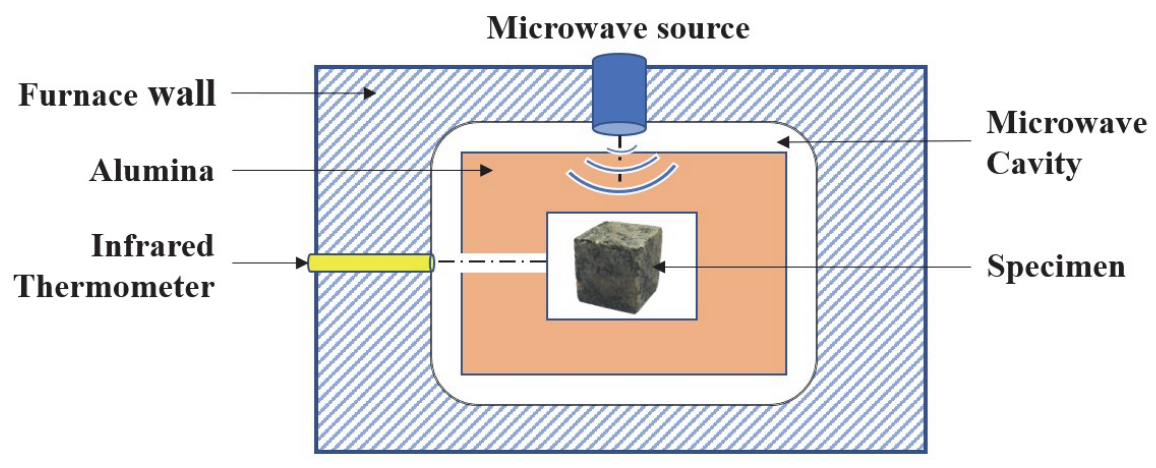

Figure 2: Schematic of the microwave muffle furnace.

\section{Characterisation}

The thermal analysis was performed using a thermal analyser device (SDT Q 600, TA) to obtain the thermo-physical properties of the analysed granite. Thermogravimetric and differential scanning calorimetry (TG-DSC) was performed at temperatures ranging from room temperature $\left(25^{\circ} \mathrm{C}\right)$ to $800{ }^{\circ} \mathrm{C}$ in air atmosphere, and the heating rate was $10^{\circ} \mathrm{C} / \mathrm{min}$. The microstructure analysis of the microwave-irradiated specimens was performed using a scanning electron microscope (SEM, EM5000, KYKY). Before and after the exposure to microwave radiation, X-ray diffraction (XRD) patterns of the analysed samples were obtained using an XRD analyser (X'Per PRO, PANalytical) to determine the changes in the composition and crystallisation. Operating conditions were: $\mathrm{Cu} \mathrm{K} \alpha$ radiation $(\lambda=1.54184 \AA)$, power $2.2 \mathrm{~kW}$, scanning speed $15^{\circ} / \mathrm{min}, 2 \theta$ ranging from $3^{\circ}$ to $80^{\circ}$. Uniaxial compressive strength (UCS) was tested to evaluate the overall trend in the damage variation in microwave-irradiated specimens, using a compression testing device (TYE-300) at the loading speed of $0.3 \mathrm{kN} / \mathrm{s}$.

\section{RESULTS}

\section{Thermal analysis}

$\mathrm{F}$ ig. 3 shows the results of the TG-DSC measurements on Qingyuan granite. A slight weight loss was detected in the $25-500{ }^{\circ} \mathrm{C}$ range; this was attributed to the mineral dehydration or water evaporation $[28,29]$. Above $600{ }^{\circ} \mathrm{C}$, a significant reduction of mass was associated with the process of dehydroxylation of biotite [30]. Above $700{ }^{\circ} \mathrm{C}$, the weight of the sample was almost unchanged. Furthermore, the curve of the heat flow exhibited an endothermic peak at 573 ${ }^{\circ} \mathrm{C}$ owing to the $\alpha$ to $\beta$ phase transition in quartz [9].

\section{Appearance and microtopography}

Fig. 4 shows the microwave-irradiated specimens. The colour of granite became shallower with increasing temperature, which was attributed to the irreversible dehydration of Fe-rich minerals [31]. It can be seen in Figs. 4a and 4b that the granite specimen exhibited no appreciable change of appearance below $400{ }^{\circ} \mathrm{C}$. Above $500{ }^{\circ} \mathrm{C}$, cracking and melting were observed 
in the dark area. The cracking could be attributed to the thermal stress while the local melting was caused by high temperature for the biotite enrichment. A clear fracture zone, parallel to the trend of schistosity, and a spot of solidified magma were observed in the dark area at $600{ }^{\circ} \mathrm{C}$. In addition, micro-cracks appeared on the surface of the light colour area. Almost all of the fracture zone of the dark area was filled with solidified magma at $700{ }^{\circ} \mathrm{C}$. Furthermore, the fracture area was pushed away by the magma, as shown in Fig. 4e. When the temperature reached $800{ }^{\circ} \mathrm{C}$, the centre of the specimen formed a big cavity owing to the melting and flow of minerals. Many micro-cracks were observed on the surface of the light area, while macro-cracks and melting occurred mainly in the dark areas at $800{ }^{\circ} \mathrm{C}$. Therefore, it can be concluded that the dark area dominantly determines the structural failure of Qingyuan granite.

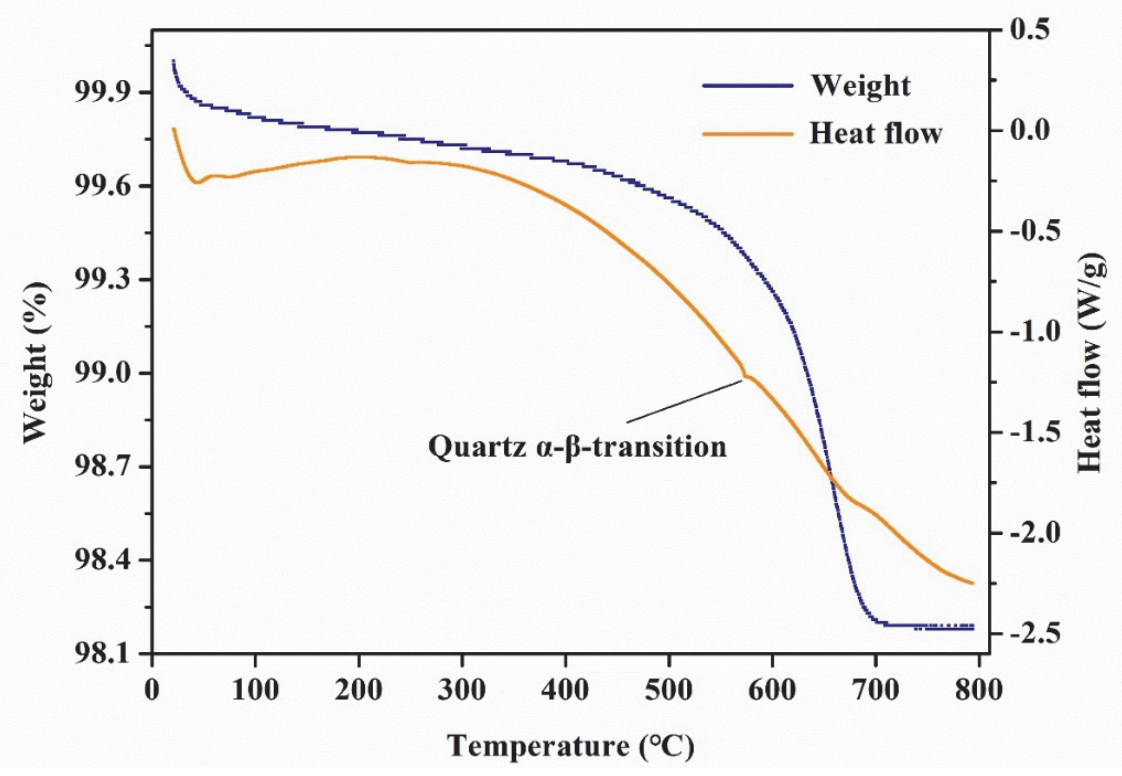

Figure 3: TG and DSC curves for pristine granite.
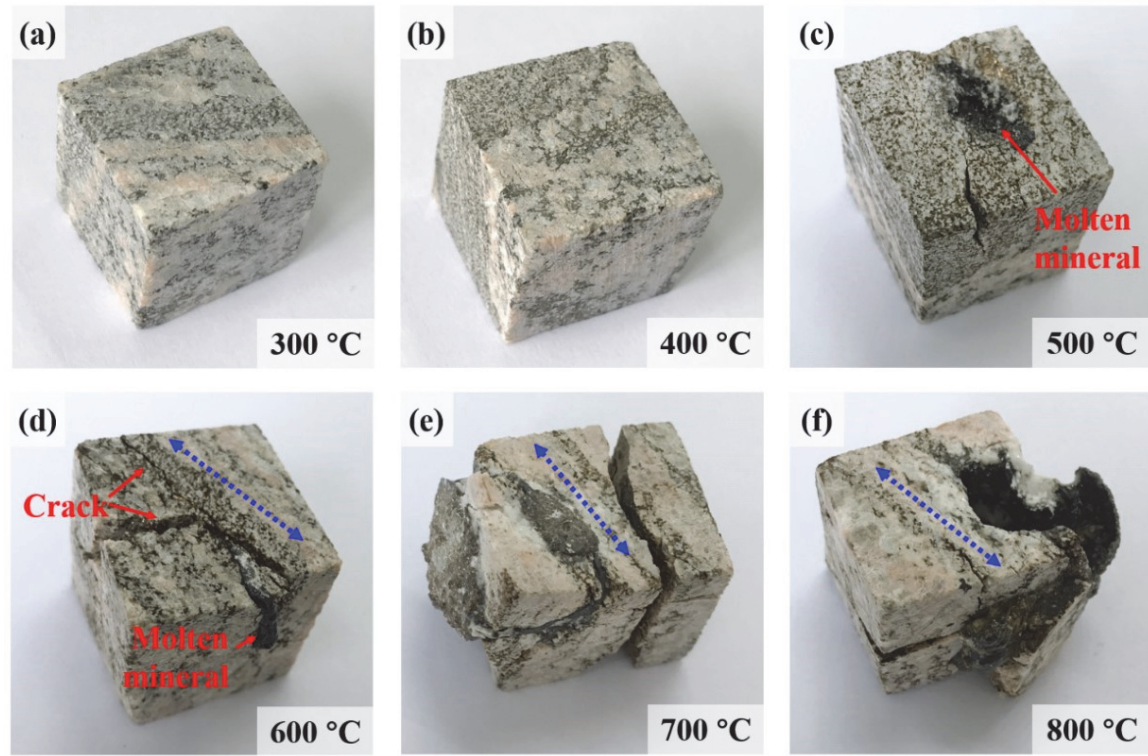

Figure 4: Appearance of specimens at different temperatures after microwave radiation.

Fig. 5 shows the microtopography of the analysed specimens at different temperatures after microwave radiation. As shown in Figs. $5 \mathrm{a}$ and $5 \mathrm{~b}$, with increasing temperature, the dimensions and the number of cracks increase. Also, two different types of cracks are observed in Fig. 5c. It is clear that there are small cracks on the left and right sides of minerals. Meanwhile, a larger-size crack can be seen at the junction between the two minerals. This demonstrates that the damage is more severe 
at the mineral junction area than within minerals. At $800{ }^{\circ} \mathrm{C}$, the surface of the molten area appeared as a smooth glass surface while the bulk contained numerous pores and cracks.
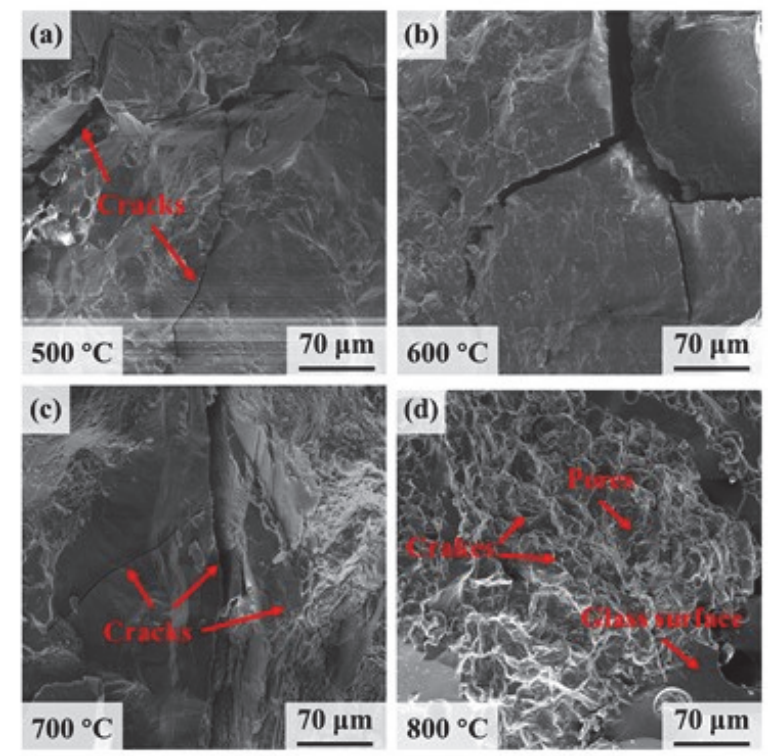

Figure 5: Microtopography of granite specimens at different temperatures after microwave radiation.

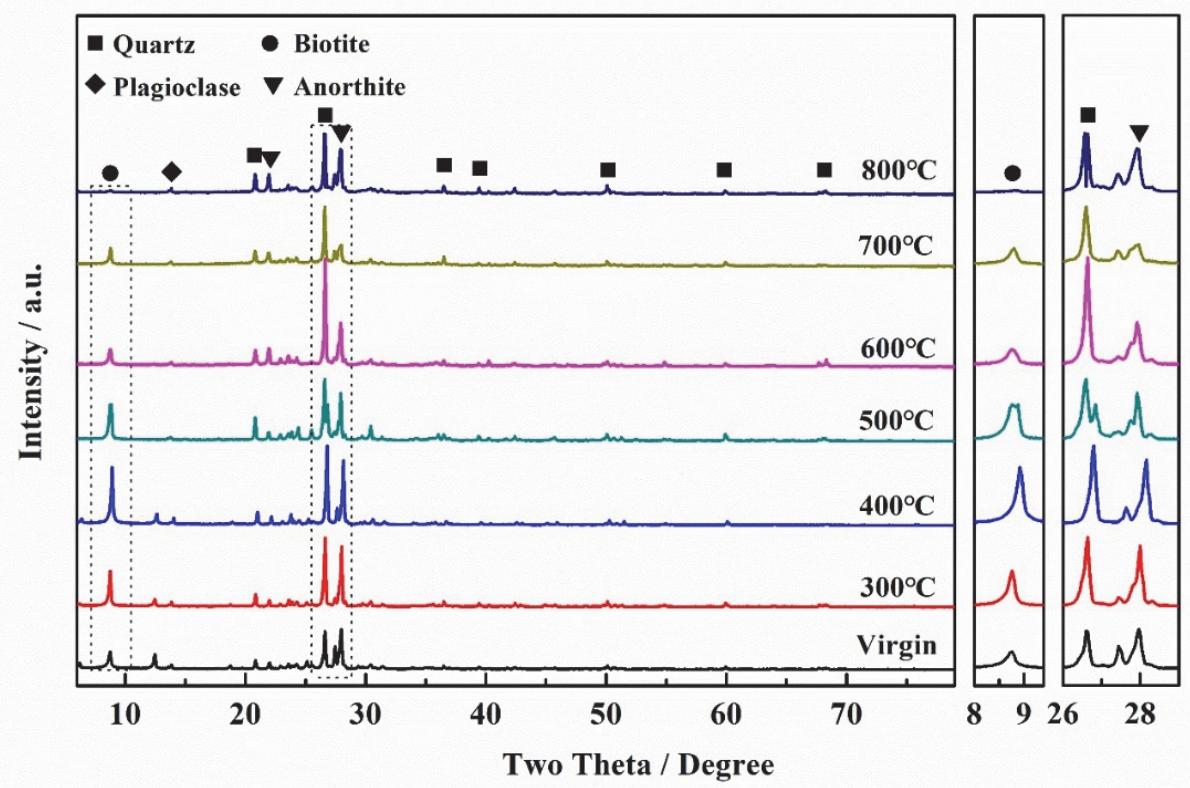

Figure 6: Powder XRD patterns of granite samples at different temperatures.

\section{XRD analysis}

Fig. 6 shows the powder XRD patterns obtained from specimens before and after microwave radiation. It can be seen that there is no distinct change in the mineral composition; however, the crystal structure of minerals changed somewhat. The diffraction peak of quartz at $2 \theta=26.5^{\circ}$ was slightly shifted toward smaller angles with increasing temperature, which also appeared for biotite at $2 \theta=8.5^{\circ}$. These trends suggest that temperature elevation induces unit cell swelling. No significant shift in the feldspar diffraction peak was observed in the XRD patterns. In addition, the diffraction peak of biotite near $2 \theta$ $=8.5^{\circ}$ decreased for temperatures above $500{ }^{\circ} \mathrm{C}$ and almost disappeared at $800{ }^{\circ} \mathrm{C}$. This demonstrates that the content and crystallisation extent of biotite decrease with increasing temperature, owing to melting. Because melting mainly occurred in 
the dark area, these results demonstrate that biotite is distributed in the dark area. This is consistent with the conclusions of XRF.

\section{Mechanical performance}

The average peak stress of the specimens before and after microwave radiation obtained from the UCS test is shown in Fig. 7. The strength decreases significantly from $122.41 \mathrm{MPa}\left(25^{\circ} \mathrm{C}\right)$ to $45.49 \mathrm{MPa}\left(600{ }^{\circ} \mathrm{C}\right)$, which is $37 \%$ of the virgin granite value. In addition, the samples' strength at $700{ }^{\circ} \mathrm{C}$ and $800{ }^{\circ} \mathrm{C}$ could not be tested, and the strength was considered small, depending on the damage. It can be deduced from Fig. 7 that the strength exhibits a relatively slow decline below $500{ }^{\circ} \mathrm{C}$. This could be attributed to the damage of the mineral crystal for losing the crystal water and structural water, which is consistent with the results of TG-DSC [28,29]. However, a sharp reduction was observed above $500{ }^{\circ} \mathrm{C}$, which was mainly owing to the schistosity cracking and internal melting in the dark area. Furthermore, the structural changes in the granite caused by the quartz phase transition at $573{ }^{\circ} \mathrm{C}$ [9] and the thermal expansion mismatch between different minerals [32] also contributed to a reduction in the curve.

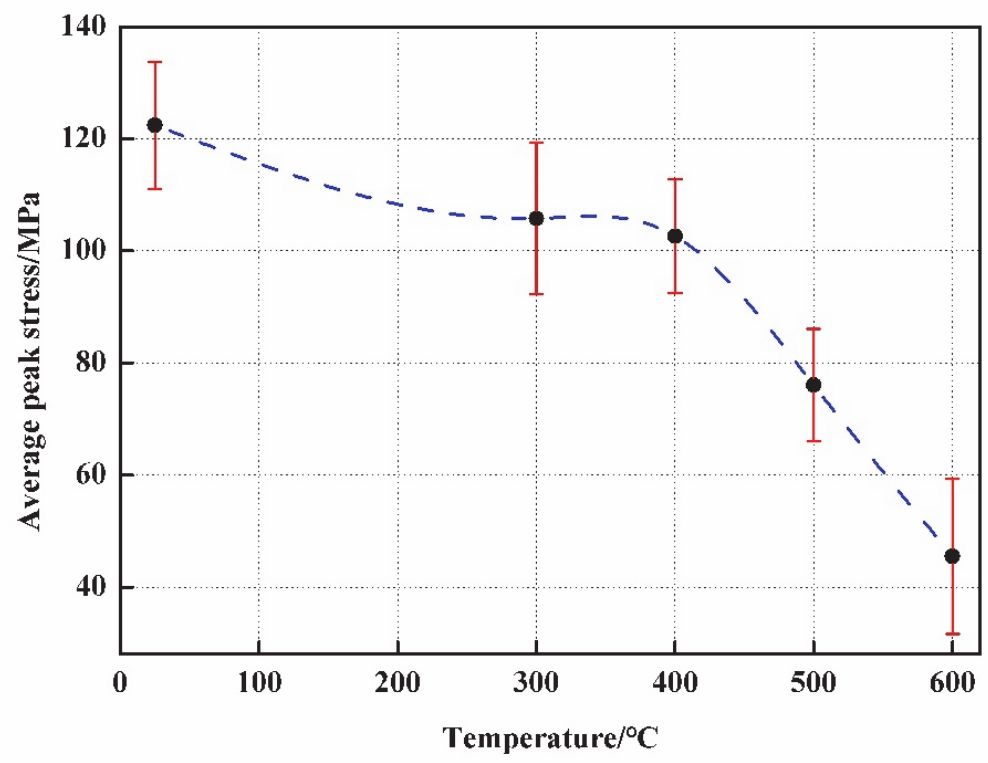

Figure 7: Average peak stress of the analysed specimens, before and after microwave radiation.

\section{Discussion}

7 he structural failure mechanism of microwave-irradiated Qingyuan granite was summarised, and the schematic diagram is shown in Fig. 8. Combined with the above analysis, the structure of the dark area was considered the main reason behind the structural failure of microwave-irradiated Qingyuan granite.

Qingyuan granite exhibits an obvious schistosity structure. According to the results in Section 2.1, most of biotite is distributed in the dark area, while the light area is mainly composed of feldspar and quartz. Such distribution of minerals induced rapid heating of the dark area upon exposure to microwave radiation. Lu et al. [7] demonstrated that a 2.5-fold volumetric expansion of biotite occurred after microwave radiation, and stress was concentrated at the boundary of the biotite crystal [32]. Ali et al. [19] considered that cracks are mostly radially oriented tensile cracks that developed from the absorbent mineral boundary (such as biotite). The colour of granite became shallower with increasing temperature, which was attributed to the irreversible dehydration of Fe-rich minerals [31], which would also induce cracking. Therefore, cracking initially appeared around the microwave-absorbing phase in the dark area.

Furthermore, it could be observed and inferred from Figs. 4d to $4 \mathrm{f}$ that most of the macro-cracks in the dark area were parallel to the schistosity trend above $600{ }^{\circ} \mathrm{C}$. This could be also attributed to the schistosity structure. Microwave radiation would weaken the connection among minerals within granite [33]. Considering that schistosity is a compressive structural plane, the authors inferred that the mineral connection in the direction perpendicular to the schistosity plane is relatively weak. Therefore, micro-cracks would develop preferentially in the direction parallel to the schistosity trend and converge 
into a major crack. In the light area, owing to the relatively high presence of quartz and feldspar, the quartz phase transition at $573{ }^{\circ} \mathrm{C}$ and the thermal expansion between different minerals would cause micro-cracks. On the other hand, when most of the minerals in the dark area reached the melting point, the magma would overflow out of these major cracks, which could even push away the adjacent light area (Figs. $4 \mathrm{~d}$ and $4 \mathrm{f}$ ). With temperature continuously increasing, a big cavity is formed in the specimen bulk, owing to the melting and flow of minerals, which also accelerates structural disintegration.

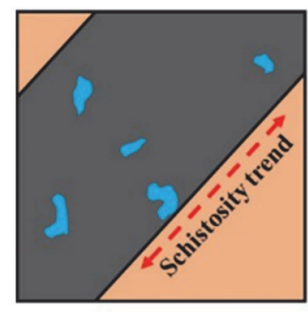

Virgin

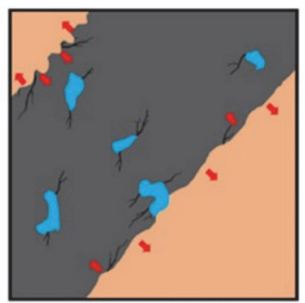

$<400{ }^{\circ} \mathrm{C}$

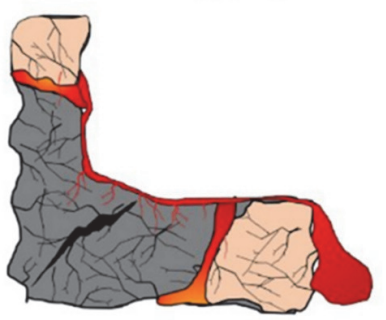

$800{ }^{\circ} \mathrm{C}$

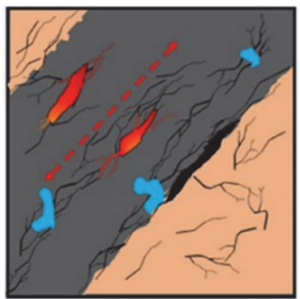

$500{ }^{\circ} \mathrm{C}$

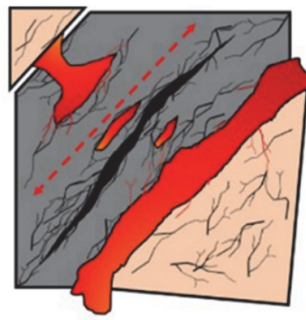

$600{ }^{\circ} \mathrm{C} \& 700{ }^{\circ} \mathrm{C}$

Dark area

Light area

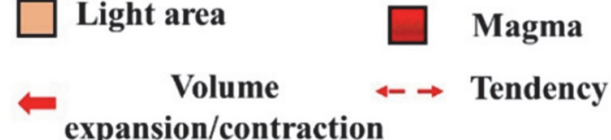

expansion/contraction

Microwave absorption

phase(biotite, magnetite)

Figure 8: Schematic of the failure process of schistosity structural granite under microwave radiation.

\section{CONCLUSIONS}

he effects of microwave radiation-induced high temperature on schistosity structural granite were investigated. Specimens were heated to different temperatures $\left(300,400,500,600,700\right.$, and $\left.800{ }^{\circ} \mathrm{C}\right)$ and kept for 15 minutes. Cracking at the cubic edge and local melting at $500{ }^{\circ} \mathrm{C}$ were owing to the thermal stress and biotite enrichment, respectively. Above $600{ }^{\circ} \mathrm{C}$, most of the macro-cracks in the dark area were parallel to the schistosity trend, owing to the weak connection in the direction perpendicular to the schistosity plane. The diffraction peak intensity of biotite decreased and even disappeared with increasing temperature, owing to the melting in the biotite-rich area. The average peak stress of the specimens significantly declined from $122.41 \mathrm{MPa}\left(25^{\circ} \mathrm{C}\right)$ to $45.49 \mathrm{MPa}\left(800{ }^{\circ} \mathrm{C}\right)$, and the strength was almost completely lost at $700{ }^{\circ} \mathrm{C}$ and above. It was concluded that microwave radiation can effectively destroy rocks by generating high temperatures. The granite samples were destroyed owing to the confluence of multiple factors, such as differences in the thermal expansion properties of minerals, loss of water, phase transformation of quartz, and hot melting. In addition, the schistosity structure of rock significantly affected the cracking pattern.

\section{ACKNOWLEDGEMENTS}

his work was supported by the National Natural Science Foundation of China (21677118). The authors would like to thank Lanjie Hou of Southwest University of Science and Technology for the help in rock mineralogical analysis.

\section{REFERENCES}

[1] Scott, G., Bradshaw, S.M., Eksteen, J.J. (2008). The effect of microwave pretreatment on the liberation of a copper carbonatite ore after milling, Int. J. Miner. Process., 85(4), pp. 121-128. 
[2] Qi, G., Wei, Z., Meng, H., Macias, F.J., Bruland, A. (2016). Free-face-Assisted Rock Breaking Method Based on the Multi-stage Tunnel Boring Machine (TBM) Cutterhead, Rock Mech. Rock Eng., 49(11), pp. 4459-4472.

[3] Walton, G., Lato, M., Anschütz, H., Perras, M.A., Diederichs, M.S. (2015). Non-invasive detection of fractures, fracture zones, and rock damage in a hard rock excavation - Experience from the Äspö Hard Rock Laboratory in Sweden, Eng. Geol., 196, pp. 210-221.

[4] Maurer, W.C. (1968). Novel drilling techniques, vol. 114, Pergamon Press New York.

[5] Kingman, S.W., Jackson, K., Cumbane, A., Bradshaw, S.M., Rowson, N.A., Greenwood, R. (2004). Recent developments in microwave-assisted comminution, Int. J. Miner. Process., 74(1), pp. 71-83.

[6] Kingman, S.W., Vorster, W., Rowson, N.A. (2000). The influence of mineralogy on microwave assisted grinding, Miner. Eng., 13(3), pp. 313-327.

[7] Lu, G.M., Li, Y.H., Hassani, F., Zhang, X. (2017). The influence of microwave irradiation on thermal properties of main rock-forming minerals, Appl. Therm. Eng., 112, pp. 1523-1532.

[8] Monti, T., Tselev, A., Udoudo, O., Ivanov, I.N., Dodds, C., Kingman, S.W. (2016). High-resolution dielectric characterization of minerals: A step towards understanding the basic interactions between microwaves and rocks, Int. J. Miner. Process., 151, pp. 8-21.

[9] Hartlieb, P., Toifl, M., Kuchar, F., Meisels, R., Antretter, T. (2016). Thermo-physical properties of selected hard rocks and their relation to microwave-assisted comminution, Miner. Eng., 91, pp. 34-41.

[10] Satish, H., Ouellet, J., Raghavan, V., Radziszewski, P. (2006). Investigating microwave assisted rock breakage for possible space mining applications, Min. Technol., 115(1), pp. 34-40.

[11] Hartlieb, P., Leindl, M., Kuchar, F., Antretter, T., Moser, P. (2012). Damage of basalt induced by microwave irradiation, Miner. Eng., 31(3), pp. 82-89.

[12] Hassani, F., Nekoovaght, P.M., Gharib, N. (2016). The influence of microwave irradiation on rocks for microwaveassisted underground excavation, J. Rock Mech. Geotech. Eng., 8(1), pp. 1-15.

[13] Peinsitt, T., Kuchar, F., Hartlieb, P., Moser, P., Kargl, H., Restner, U., Sifferlinger, N.A. (2010). Microwave heating of dry and water saturated basalt, granite and sandstone, Int. J. Min. Miner. Eng., 2(1), pp. 18-29(12).

[14] John, R.S., Batchelor, A.R., Ivanov, D., Udoudo, O.B., Jones, D.A., Dodds, C., Kingman, S.W. (2015). Understanding microwave induced sorting of porphyry copper ores, Miner. Eng., 84, pp. 77-87.

[15] Zheng, Y.L., Zhang, Q.B., Zhao, J. (2017). Effect of microwave treatment on thermal and ultrasonic properties of gabbro, Appl. Therm. Eng., 127, pp. s1359431117306622.

[16] Whittles, D.N., Kingman, S.W., Reddish, D.J. (2003). Application of numerical modelling for prediction of the influence of power density on microwave-assisted breakage, Int. J. Miner. Process., 68(1), pp. 71-91.

[17] Jones, D.A., Kingman, S.W., Whittles, D.N., Lowndes, I.S. (2005). Understanding microwave assisted breakage, Miner. Eng., 18(7), pp. 659-669.

[18] Jones, D.A., Kingman, S.W., Whittles, D.N., Lowndes, I.S. (2007). The influence of microwave energy delivery method on strength reduction in ore samples, Chem. Eng. Process. Process Intensif., 46(4), pp. 291-299.

[19] Ali, A.Y., Bradshaw, S.M. (2010). Bonded-particle modelling of microwave-induced damage in ore particles, Miner. Eng., 23(10), pp. 780-790.

[20] Wang, Y., Djordjevic, N. (2014). Thermal stress FEM analysis of rock with microwave energy, Int. J. Miner. Process., 130(28), pp. 74-81.

[21] Meisels, R., Toifl, M., Hartlieb, P., Kuchar, F., Antretter, T. (2015). Microwave propagation and absorption and its thermo-mechanical consequences in heterogeneous rocks, Int. J. Miner. Process., 135(3), pp. 40-51.

[22] Toifl, M., Meisels, R., Hartlieb, P., Kuchar, F., Antretter, T. (2016). 3D numerical study on microwave induced stresses in inhomogeneous hard rocks, Miner. Eng., 90, pp. 29-42.

[23] Ghazvinian Vaneghi, G., Hadei, M., R., Azinfar, M. J. (2013). Shear behavior of inherently anisotropic rocks, Int. J. Rock Mech. Min. Sci., 61(7), pp. 96-110.

[24] Liu, H.Z., Xie, H.Q., He, J.D., Xiao, M.L., Zhuo, L. (2016). Nonlinear creep damage constitutive model for soft rocks, Mech. Time-Dependent Mater., 21(1), pp. 1-24.

[25] Zhang, W., Qian, H., Sun, Q., Chen, Y. (2015). Experimental study of the effect of high temperature on primary wave velocity and microstructure of limestone, Environ. Earth Sci., 74(7), pp. 5739-5748.

[26] Yin, T.B., Shu, R.H., Xi-Bing, L.I., Wang, P., Liu, X.L. (2016). Comparison of mechanical properties in high temperature and thermal treatment granite, Trans. Nonferrous Met. Soc. China, 26(7), pp. 1926-1937.

[27] Yao, M., Rong, G., Zhou, C., Peng, J. (2016). Effects of Thermal Damage and Confining Pressure on the Mechanical Properties of Coarse Marble, Rock Mech. Rock Eng., 49(6), pp. 2043-2054. 
[28] Sun, Q., Zhang, W., Xue, L., Zhang, Z., Su, T. (2015). Thermal damage pattern and thresholds of granite, Environ. Earth Sci., 74(3), pp. 2341-2349.

[29] Zuo, J.P., Wang, J.T., Sun, Y.J., Chen, Y., Jiang, G.H., Li, Y.H. (2017). Effects of thermal treatment on fracture characteristics of granite from Beishan, a possible high-level radioactive waste disposal site in China, Eng. Fract. Mech., 182, pp. s0013794416304076.

[30] Labus, M., Lempart, M. (2018). Studies of polish Paleozoic shale rocks using FTIR and TG/DSC methods, J. Pet. Sci. Eng., 161, pp. 311-318.

[31] Becattini, V., Motmans, T., Zappone, A., Madonna, C., Haselbacher, A., Steinfeld, A. (2017). Experimental investigation of the thermal and mechanical stability of rocks for high-temperature thermal-energy storage, Appl. Energy, 203, pp. 373-389.

[32] Vázquez, P., Shushakova, V., Gómez-Heras, M. (2015). Influence of mineralogy on granite decay induced by temperature increase: Experimental observations and stress simulation, Eng. Geol., 189, pp. 58-67.

[33] Chen, Y.L., Wang, S.R., Ni, J., Azzam, R., Fernández-Steeser, T.M. (2017). An experimental study of the mechanical properties of granite after high temperature exposure based on mineral characteristics, Eng. Geol., 220, pp. 234-242. 